\title{
Expression and Localization of Proteins of the Complement System in Human Skin
}

Nebojsa Dovezenski, Rosario Billetta, and Irma Gigli

Department of Medicine, Division of Dermatology, University of California, San Diego School of Medicine, San Diego, California 92103

\begin{abstract}
The complement system participates in the immune recognition of foreign antigens, many of which may penetrate the skin by physical injury or transcutaneous adsorption. In this study, we examined the presence of complement components and complement regulatory proteins in the human skin and cultured human keratinocytes. Immunofluorescence studies showed C3, Factor $B$, decay accelerating factor, the $\mathrm{C} 3 \mathrm{~b}$ receptor (CR1), and $\mathrm{C} 3 \mathrm{~d}$ receptor (CR2), distributed among cells of the epidermis as well as on cultured keratinocytes. Immunoblot analysis of keratinocytes supernatants showed the presence of $\mathrm{C} 3$ with a molecular weight of $\sim 180 \mathrm{kD}$. The decay accelerating factor was localized as previously reported on elastic fibers; additionally it was observed in the basement membrane zone. In situ hybridization studies suggest the expression of CR1 and CR2 mRNA in human epidermis. These results show the presence in the human epidermis of complement components that are capable of generating the initial C3 convertase of the alternative pathway. The presence of complement regulatory proteins could endow keratinocytes with immune functions such as the regulation of complement activation and endocytosis of $\mathrm{C} 3$ opsonized particles. (J. Clin. Invest. 1992. 90:2000-2012.) Key words: CR1 • CR2 - decay accelerating factor $\cdot \mathrm{C} 3 \cdot$ Factor $B$
\end{abstract}

\section{Introduction}

The complement system is a complex group of proteins that mediates biologically important reactions ranging from lysis of cells, bacteria, and viruses to initiation of the humoral portion of the inflammatory response, and stimulation of immunocytes through receptor-ligand interactions (reviewed in 1). Complement activation is mediated by two distinct pathways, the classical (antibody dependent) and alternative (antibody independent). Both eventuate in the activation of C5 leading to the formation of the membrane attack complex (2). The system is controlled by serum proteins such as Factor $\mathbf{H}$ (3), Factor I (4), C4b binding protein (C4bp) (5), and the membrane proteins $C 3 b$ receptor $(C R 1)(6), C 3 d$ receptor (CR2) (7), membrane cofactor protein (MCP) (8), decay accelerating factor $(\mathrm{DAF})^{1}(9)$, and the homologous restriction factors (10). These

Address reprint requests to Dr. Irma Gigli, Division of Dermatology (8420), University of California, San Diego, Medical Center, 225 Dickinson Street, San Diego, CA 92103-8420.

Received for publication 29 May 1991 and in revised form 30 October 1991.

J. Clin. Invest.

(C) The American Society for Clinical Investigation, Inc.

$0021-9738 / 92 / 11 / 2000 / 13 \$ 2.00$

Volume 90, November 1992, 2000-2012 proteins are widely distributed on the surface of blood and tissue cells.

In addition to cytolysis, the role of complement is effected by three kinds of products generated during complement activation, namely antigen bound components, inactive fluid phase fragments and enzymatically released peptides, all of which may serve as ligands for specific receptors on a variety of cells. Although plasma complement proteins are primarily synthesized in the liver, a wide variety of extrahepatic cells have been reported to be capable of synthesizing complement components and regulatory proteins. $\mathrm{C} 3$, for example, has been found to be secreted by monocytes, lung macrophages, and skin fibroblasts. Such secretion of complement proteins by a variety of cell types is thought to contribute to the local concentration of these proteins in specific tissues (reviewed in reference 11). The production of complement by keratinocytes would allow the epidermis to form a first line of immunologic defense. The presence of complement receptors and regulatory proteins could protect these cells from the random deposition of activated complement components, and endow keratinocytes with the capacity to generate biologically active fragments, primarily those derived from C3. Because human epidermis is in continuous contact with foreign antigens, we studied the presence of complement proteins and receptors in epidermal cells.

\section{Methods}

Human skin. Normal human skin was obtained from healthy volunteers by shave or punch biopsy following the local injection of $1 \%$ lidocaine. Human foreskin was obtained from newborn circumcisions.

Antibodies. Anti-CR1 monoclonal antibody 543 was previously reported (12), 44F anti-CR1 as well as HB5 anti-CR2 were purchased from Becton Dickinson (Mountain View, CA). Anti-CR2, OKB7 was purchased from Ortho Pharmaceuticals (Raritan, NJ). Monoclonal antibodies to biological cleavage products of $\mathrm{C} 3$ and $\mathrm{C} 4$, as well as Factor B, Factor H, and Factor I, were purchased from Quidell (San Diego, CA). pBluescript was purchased from Stratagene Inc. (La Jolla, CA). Polyclonal goat anti-C3 and monoclonal anti-C5 were the gift of Dr. H. J. Müller-Eberhard (Hamburg, Germany). Nonimmune isotypic mouse $\mathrm{IgG}_{1}$ and $\mathrm{IgG}_{2 \mathrm{a}}$ used as controls were purchased from Coulter Immunology (Hialeah, FL). Monoclonal anti-DAF IgG $_{1}$ was a gift of Dr. M. Davitz (New York University). FITC-goat anti-mouse affinitypurified Fab'2 were purchased from Caltag Laboratories (South San Francisco, CA).

Cultured keratinocytes. Keratinocytes were generously provided by Dr. J. Hansbrough, University of California, San Diego. These were obtained free of fibroblasts from human skin according to the method of Boyce and Ham (13) and grown to semiconfluency in serum-free keratinocyte growth medium (KGM ${ }^{\mathrm{TM}}$; Clonetics Corp., San Diego, CA), in plastic chamber slides (Nunc Inc., Naperville, IL) or $150-\mathrm{ml}$

1. Abbreviations used in this paper: $\mathrm{CR} 1, \mathrm{C} 3 \mathrm{~b}$, receptor; $\mathrm{CR} 2, \mathrm{C} 3 \mathrm{~d}$ receptor; DAF, decay accelerating factor; MCP, membrane cofactor protein. 
plastic flasks (Becton Dickinson). The keratinocyte culture supernatants were collected and mixed with the following protease inhibitors at the following final concentrations: $1 \mathrm{mM}$ epsilon-amino- $n$-caproic acid, $1 \mathrm{mM}$ benzamidine hydrochloride, $5 \mathrm{mM}$ EDTA, $1 \mathrm{mM}$ PMSF, and $0.02 \%$ sodium azide (Sigma Chemical Co., St. Louis, MO). A total of $450 \mathrm{ml}$ of supernatant was collected and stored at $-80^{\circ} \mathrm{C}$ until used. Upon thawing of the supernatant (overnight on ice), the final concentration of EDTA was brought to $10 \mathrm{mM}$ and the material was filtered through a $0.22-\mu \mathrm{m}$ filter to remove any particulate material present.

Isolation of $C 3$ from keratinocyte culture supernatant. An immunoabsorbent gel was prepared by coupling to $2 \mathrm{ml}$ of Affi-Gel 10 (BioRad Laboratories, Richmond, CA) $50 \mathrm{mg}$ of anti-C3 IgG isolated from goat anti-human C3 by precipitation with Rivanol (Sigma Chemical Co.) followed by ion exchange chromatography. A small glass column was packed with washed immunoabsorbent gel and the $450 \mathrm{ml}$ of keratinocyte culture fluid was applied in a close-loop at a flow rate of 0.5 $\mathrm{ml} / \mathrm{min}$ at $4^{\circ} \mathrm{C}$ for $24 \mathrm{~h}$.

$S D S-P A G E$ and immunoblot. After the affinity chromatography was completed, $200 \mu \mathrm{l}$ of wet immunoabsorbent gel was dried by centrifugation. The dried gel was boiled in $200 \mu$ l of sample buffer containing $8 \%$ SDS and subjected to a 7.5\% SDS-PAGE according to Laemmli (14). After electrophoresis, the proteins were transferred to an Immobilon membrane (Millipore Corp., Bedford, MA) using a semi-dry system (Bio-Rad Laboratories). The membrane was reacted with a mouse monoclonal anti-human C3c (Quidell) at 1:12,000 dilution for $1 \mathrm{~h}$ at room temperature. As a secondary antiserum, an immunoblot grade goat anti-mouse IgG alkaline phosphatase conjugate (Bio-Rad Laboratories) was used at 1:3,000 dilution for $1 \mathrm{~h}$ at room temperature. The membrane was subsequently reacted with 5-bromo-4-chloro-3-imdolyl phosphate and nitroblue tetrazolium (Bio-Rad Laboratories).

Because the preparation of keratinocytes from human skin for culture requires the use of trypsin and subsequent addition of small amounts of fetal calf serum as trypsin inhibitor, control experiments were performed to test whether the monoclonal anti-human $\mathrm{C} 3 \mathrm{c}$ antibody cross-reacts with bovine $\mathrm{C} 3$ which might have been present in culture supernatants. To maximize the sensitivity of the reaction a dot-blot immunoassay was used with the same monoclonal anti-human C $3 \mathrm{c}$ antibody as used in immunoblot of supernatants and two additional polyclonal anti-C3 sera. Fetal calf serum undiluted or diluted to $5 \%$ in medium, undiluted $\mathrm{KGM}^{\mathrm{TM}}$ medium, supernatant of cultures of keratinocytes or highly diluted normal human plasma as positive control were slowly suctioned through the nitrocellulose membrane using low household vacuum and a dot-blot apparatus (Bio-Rad Laboratories). No reactivity was observed between the samples and any of the anti-C3 antisera tested.

Immunofluorescent studies. Human skin was snap frozen in Tissue Tek O.C.T. (Miles Scientific Div., Miles Laboratories Inc., Naperville, IL) over dry ice. 4- $\mu \mathrm{m}$ thick sections were cut and fixed in cold acetone for $10 \mathrm{~min}$, washed in PBS, and blocked for $30 \mathrm{~min}$ in PBS containing $2 \%$ BSA (Sigma Chemical Co.). The samples were then incubated overnight with $50 \mu \mathrm{l}$ of PBS-1\% BSA, containing $1 \mu \mathrm{g}$, respectively, of monoclonal antibodies to: C3c, C3d, C4c, C4d, C5, Factor B, Factor I, Factor $\mathrm{H}, \mathrm{CR} 1, \mathrm{CR} 2$, DAF, or with identical amounts of the corresponding isotypic nonimmune IgG as control. After $16 \mathrm{~h}$ at $4^{\circ} \mathrm{C}$, the slides were washed five times in PBS, and incubated for $1 \mathrm{~h}$ at $22^{\circ} \mathrm{C}$ with $50 \mu \mathrm{l}$ of FITC goat Fab'2 anti-mouse IgG at a concentration of $20 \mu \mathrm{g} / \mathrm{ml}$. The tissue was then washed, mounted, and examined with a fluorescent microscope.

Cultured keratinocytes, when used, were fixed on the chamber slides, and treated in identical fashion as the skin sections.

Detection of CRI and CR 2 mRNA in the epidermis by in situ hybridization. Plasmids containing CR1 (15) (American Type Culture Collection, Rockville, MD) and CR2 (16) cDNA inserts (generous gift of Dr. G. Nemerow, Scripps Clinic, La Jolla, CA) were labeled by nick translation (17). Briefly, $0.5 \mu \mathrm{g}$ of CR1 cDNA was incubated for $45 \mathrm{~min}$ at room temperature with $100 \mu \mathrm{M}$ of deoxynucleoside triphosphates (dNTP) containing digoxigenin coupled-dUTP (Dig-dUTP) (Boehringer Mannheim Biochemicals, Indianapolis, IN), 10 U of DNA poly- merase (Bethesda Research Laboratories [BRL], Bethesda, MD), and an optimal concentration of DNase (gift of Dr. C. Zuker, University of California, San Diego, San Diego, CA) which was previously calibrated to result in DNA fragments of $\sim 100 \mathrm{bp}(3 \mu \mathrm{g} / \mathrm{ml})$. Unincorporated dNTP was removed by a Sephadex G-50 spin column and the DNA precipitated by ethanol/sodium acetate. After drying, the probes were resuspended in $300 \mu \mathrm{g}$ of prehybridization solution $(0.6 \mathrm{M} \mathrm{NaCl}, 10$ mM Tris; 1 mM EDTA, $1 \times$ Denhardt's solution, $10 \%$ dextran sulfate, $50 \%$ deionized high purity formamide [Fisher Scientific Co., Fairlawn, NJ), $0.5 \mathrm{mg} / \mathrm{ml}$ transfer RNA (Sigma Chemical Co.), $0.1 \mathrm{mg} / \mathrm{ml}$ sheared denatured salmon sperm DNA, pH 7.5 (Sigma Chemical Co.).

Alternatively, we prepared digoxigenin-labeled CR2 cDNA oligonucleotides by "run off synthesis" using a combination of published protocols $(18,19)$. Briefly, $100 \mathrm{ng}$ of a $1.6-\mathrm{kb}$ insert CR2 cDNA in pBluescript were digested with either $1 \mathrm{U}$ of the restriction enzymes $\mathrm{Bgl} I$ or NdeI. These enzymes digest sites in the insert $50 \mathrm{bp}$ from the $5^{\prime}$ end and $3^{\prime}$ ends, respectively. Run off polymerization was carried out using 0.1 $\mu \mathrm{g}$ of the digested DNA templates, $2 \mu \mathrm{M}$ of T3 or T7 primers, $140 \mu \mathrm{M}$ of each dNTP, $100 \mu \mathrm{M}$ digoxigenin-11-dUTP, and 1.5 U Taq polymerase (Gibco BRL) in a total vol of $50 \mu 1$ of $10 \mathrm{mM}$ Tris, pH 8.3, $50 \mathrm{mM}$ $\mathrm{KCl}, 1.5 \mathrm{mM} \mathrm{MgCl}_{2}, 0.01 \%$ gelatin. These reagents were prepared under sterile conditions. The solution was overlaid with paraffin oil, and the polymerization reaction performed in a DNA thermal cycler (Perkin-Elmer Cetus Instruments, Norwalk, CT) for $40-80$ cycles as follows: $1 \mathrm{~min}$ at $94^{\circ} \mathrm{C}, 2 \mathrm{~min}$ at $45^{\circ} \mathrm{C}$, and $3 \mathrm{~min}$ at $72^{\circ} \mathrm{C}$. Transcription from the $\mathrm{T} 7$ promoter gave rise to the antisense strand, whereas the T3 promoter generated the sense strand used as negative control for hybridization studies. Unincorporated dNTPs were separated by $\mathrm{NH}_{4} \mathrm{AC} / \mathrm{ETOH}$ precipitation and the probes were finally resuspended in $200 \mu$ l of hybridization solution.

6- $\mu \mathrm{m}$ thick sections were cut form frozen human skin and layered over acid cleaned glass slides pretreated with $50 \mu \mathrm{g} / \mathrm{ml}$ poly-L-lysine (Sigma Chemical Co.) for $30 \mathrm{~min}$. The tissue was allowed to air dry for $20 \mathrm{~min}$, fixed in $4 \%$ paraformaldehyde-PBS (Polysciences Inc., Warrington, PA), for $20 \mathrm{~min}$, digested for $2 \mathrm{~min}$ with $5 \mu \mathrm{g} / \mathrm{ml}$ of proteinase $K$, and washed in PBS-glycine (Sigma Chemical Co.) $(2 \mathrm{mg} / \mathrm{ml}$ ). After refixing with paraformaldehyde for an additional $20 \mathrm{~min}$, the tissue was ready for prehybridization.

Hybridization was performed using the Genius kit (Boehringer Mannheim), following the manufacturer's instructions with minor variations. Briefly, tissue slides were incubated with $50 \mu \mathrm{l}$ heat denatured hybridization solution for $60 \mathrm{~min}$ at $37^{\circ} \mathrm{C}$, after which they were hybridized at $37^{\circ} \mathrm{C}$ with $30 \mu \mathrm{l}$ of boiled hybridization solution containing $10 \%$ $\mathrm{vol} / \mathrm{vol}$ digoxigenin labeled probes. Negative controls consisted of identically labeled vectors lacking DNA inserts. After $16 \mathrm{~h}$, the slides were washed for $4 \mathrm{~h}$ in eight changes of $50 \%$ formamide, $0.6 \mathrm{M} \mathrm{NaCl}, 10 \mathrm{mM}$ Tris (pH 7.5), $1 \mathrm{mM}$ EDTA at $37^{\circ} \mathrm{C}$. The tissue was incubated for $1 \mathrm{~h}$ at room temperature with PBS containing 0.1\% Saponin, 2\% normal sheep serum, and $0.024 \%$ levamisole, and then reacted with the same solution lacking levamisole and containing a 1:500 dilution of the commercial antidigoxigenin Fab fragments coupled to alkaline phosphatase for $2 \mathrm{~h}$ at room temperature. This was followed by washing with 10 changes of PBS- $0.1 \%$ Saponin. The presence of mRNA was revealed by the nitroblue tetrazolium reaction, following manufacturer's instructions.

\section{Results}

Cell membrane regulatory proteins of complement in human epidermis and cultured human keratinocytes. The expression of the receptors CR1 and CR2 was examined using two approaches: immunofluorescence of human skin and cultured keratinocytes, and in situ hybridization in human skin. The monoclonal anti-CR 1 antibodies used $(44 \mathrm{~F}$ and 543$)$ reacted with keratinocytes localized in the basal layer of the epidermis. CR1 appeared to be distributed primarily on the cell membrane, with faint fluorescence being present in the cytoplasm 

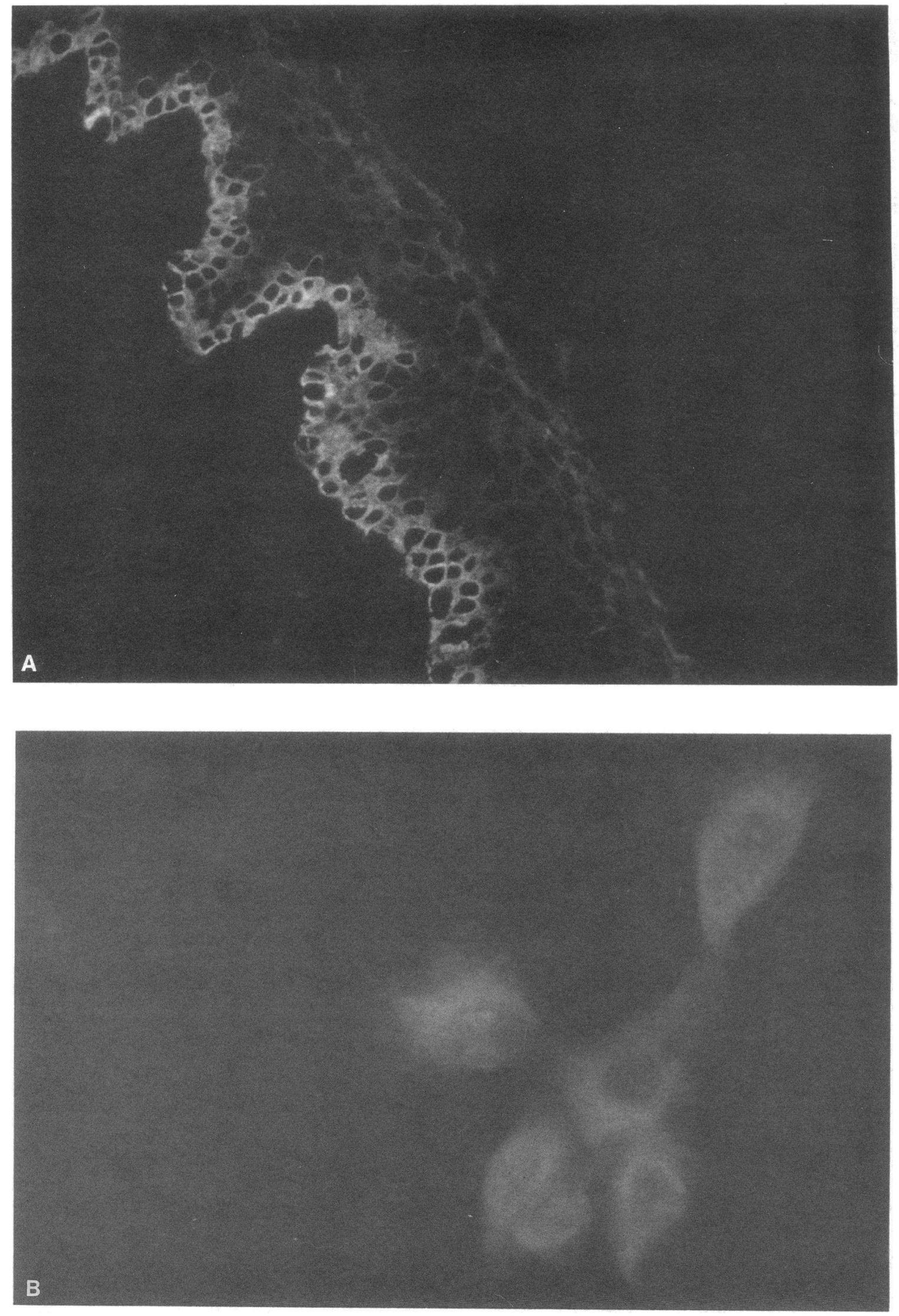

Figure 1. Expression of $\mathrm{CR} 1$ in human epidermis and cultured keratinocytes. Immunofluorescence of human skin $(A)$ and cultured keratinocytes $(B)$. In situ hybridization using digoxigenin labeled CR1 cDNA $(C)$. Nonimmune IgG1 $(D)$. 

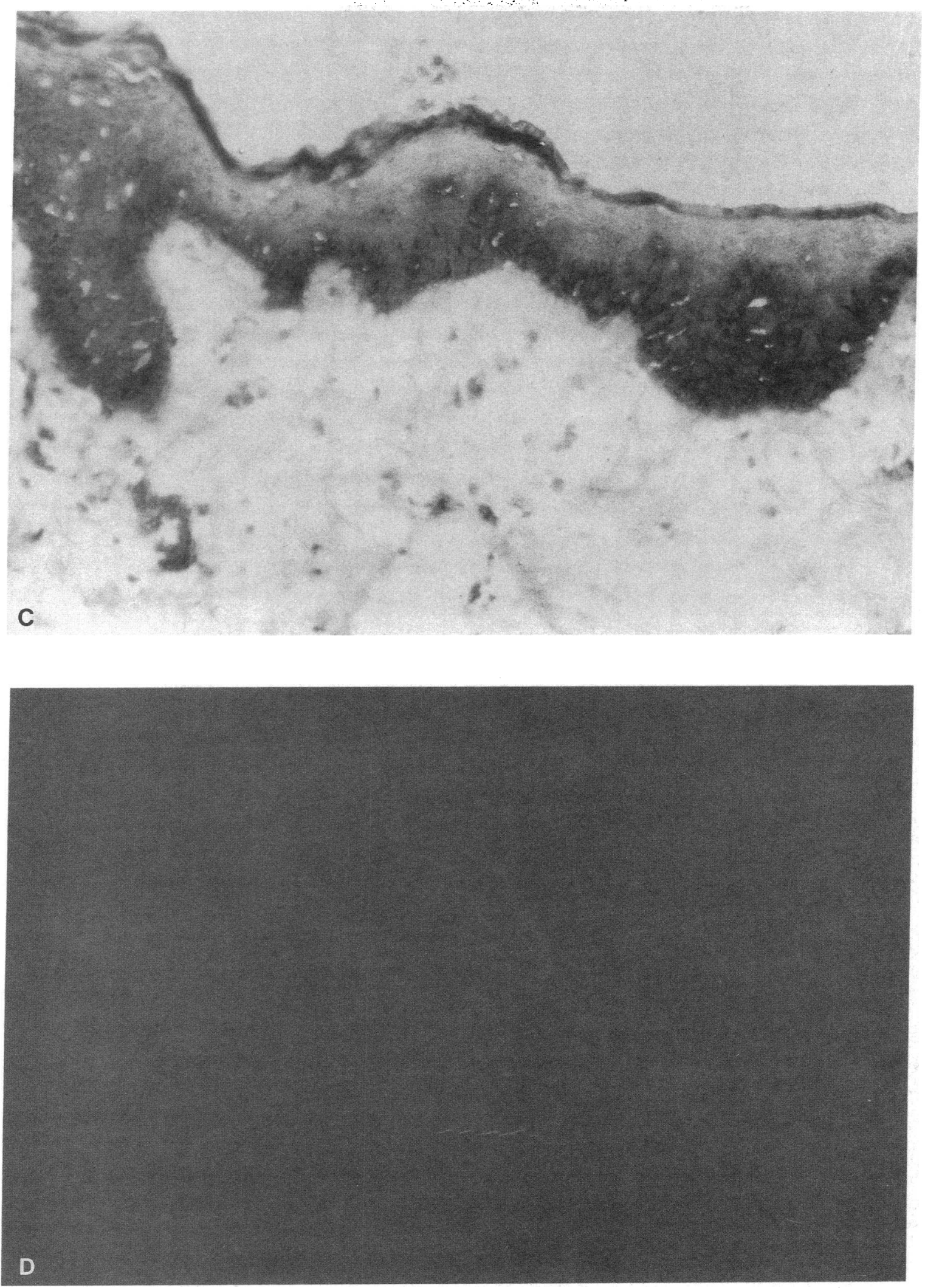

Figure 1 (Continued) 

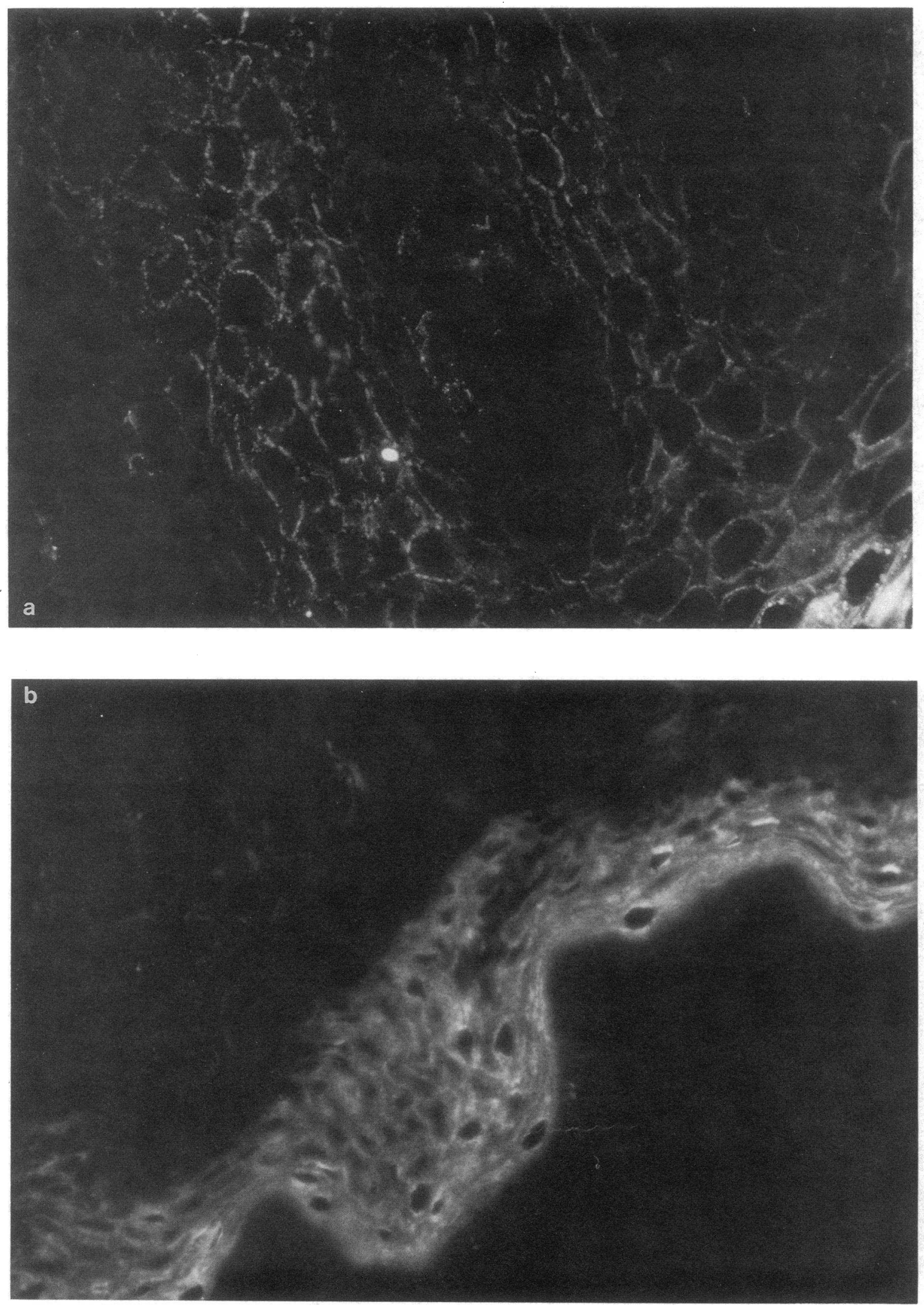

Figure 2. Expression of CR2 in human epidermis. Immunofluorescence appears predominantly in a granular pattern on the cell membrane of spinous keratinocytes $(a)$, and to a lesser degree in a superficial cytoplasmic distribution $(b)$. No staining was observed in cultured keratinocytes. 

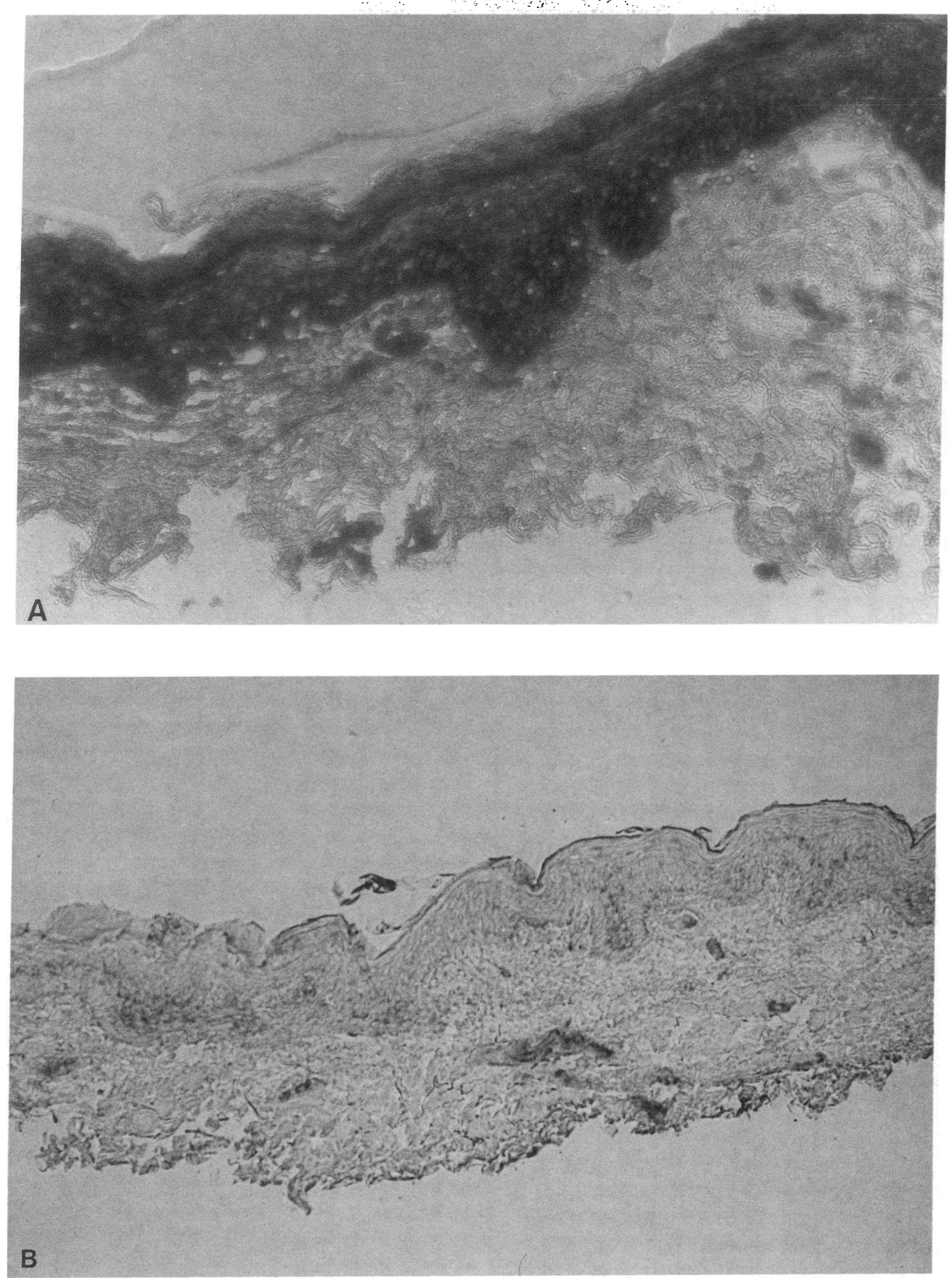

Figure 3. CR2 mRNA in human epidermis by in situ hybridization. Probes containing a 1.6-kb insert CR2 cDNA hybridized with keratinocytes throughout the epidermis $(A)$, while plasmids devoid of inserts did not $(B)$. 

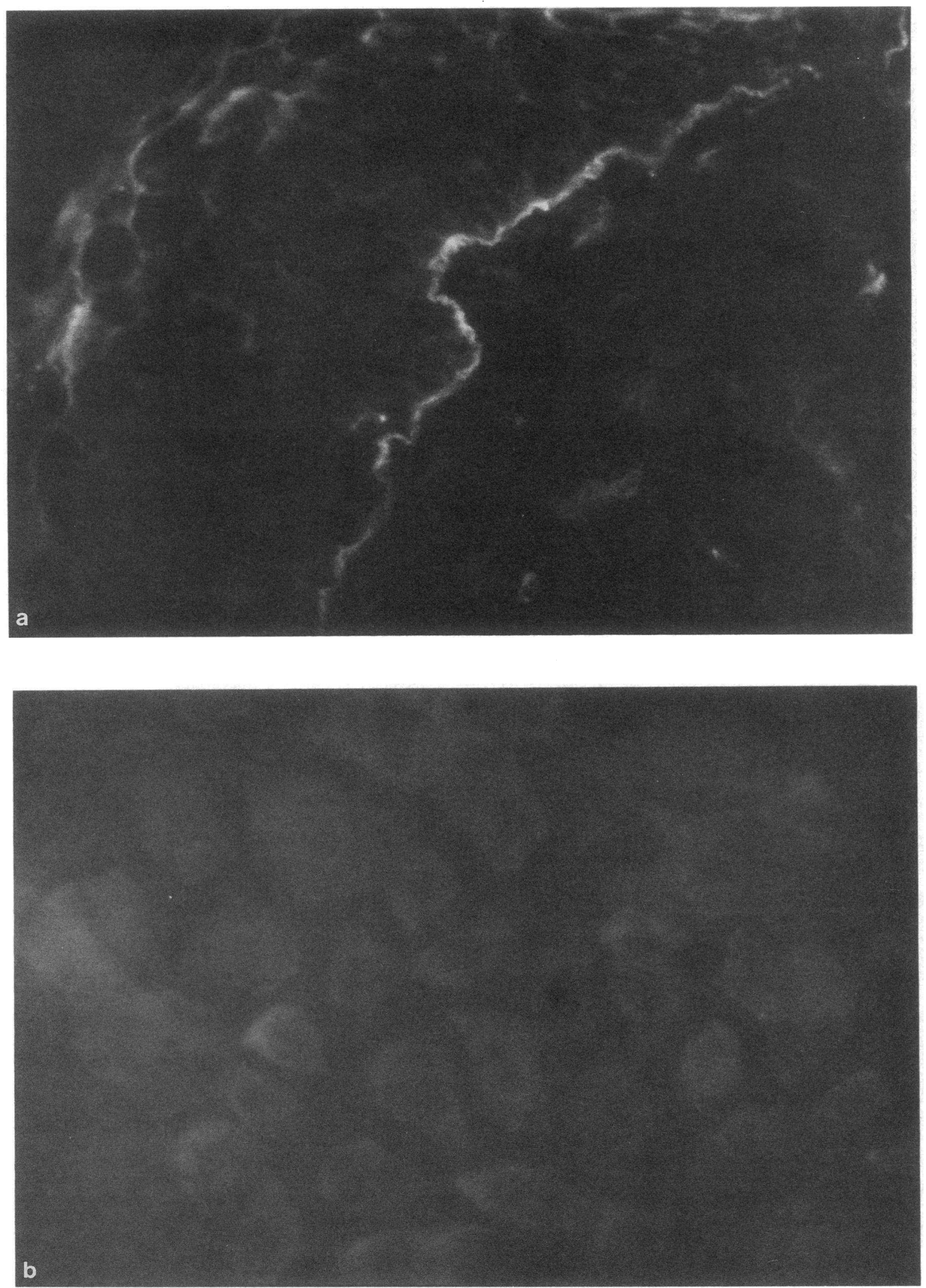

Figure 4. Expression of decay accelerating factor in human epidermis. Immunofluorescence of adult human skin $(a)$ and cultured keratinocytes $(b)$. 

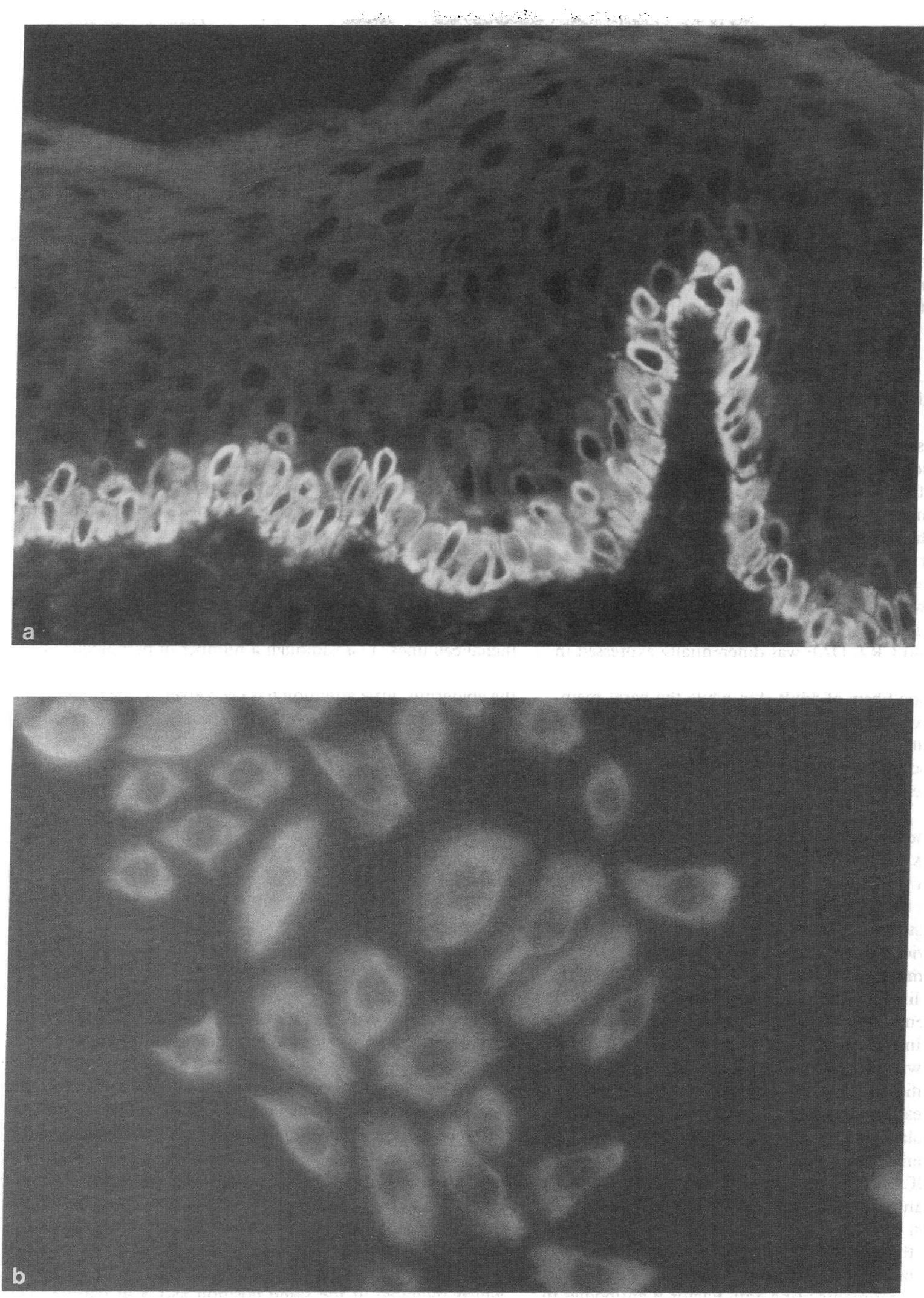

Figure 5. Expression of $\mathrm{C} 3$ in human epidermis. Immunofluorescence of human skin (a) and cultured keratinocytes (b) using a monoclonal antibody to C3c. 
(Fig. $1 A$ ). This receptor was also detected by immunofluorescence in cultured keratinocytes where it could be observed throughout the cells (Fig. $1 B$ ). In situ hybridization using digoxigenin labeled CR1 cDNA showed the expression of this mRNA distributed primarily in the keratinocytes of the lower half of the epidermis (Fig. 1C). The negative control consisting of isotypic IgG is shown in Fig. $1 D$.

CR2 was visualized using the monoclonal antibody HB5. It was present on keratinocytes of the superficial two-thirds of the epidermis, and no fluorescence was observed in the basal layer. It appeared predominantly in a granular pattern on the cell membrane of spinous keratinocytes (Fig. $2 a$ ), and to a lesser degree in a superficial cytoplasmic distribution (Fig. $2 b$ ). No staining could be observed in skin reacted with another antiCR2 monoclonal antibody, OKB7. Nick-translated probes obtained from the 1.6-kb insert CR2 cDNA, hybridized with keratinocytes throughout the epidermis, whereas plasmids devoid of inserts did not (Fig. 3, $A$ and $B$ ). Furthermore, labeled DigDUTP antisense ssDNA probes were obtained by "run off synthesis" and hybridized to the cytoplasm of keratinocytes with the same distribution. Sense strands were negative (not shown).

Another membrane associated regulatory protein, the decay accelerating factor, previously demonstrated in the elastic fibers in the dermis (20), was also investigated. Anti-DAF monoclonal antibodies reacted with elastic fibers in the dermis, but in addition, we found a linear continuous deposit of DAF in the basement membrane zone (Fig. $4 a$ ). Contrary to findings with CR1 and CR2, DAF was differentially expressed in newborn foreskin and adult skin. DAF expression predominated in the elastic fibers of adult skin while the basal membrane deposits were more striking in newborn foreskin (Fig. 4 a). Cultured keratinocytes from adult skin showed a faint, but recognizable, fluorescence, which in most cells was concentrated at one pole (Fig. $4 b$ ).

Complement proteins in human epidermis and cultured keratinocytes. The presence of $\mathrm{C} 3$ was investigated using monoclonal antibodies to the $\mathrm{C} 3 \mathrm{c}$ portion of the molecule. These reacted with the cytoplasm of the keratinocytes localized in the basal layer of the epidermis (Fig. $5 a$ ). Keratinocytes in culture also showed strong cytoplasmic staining (Fig. $5 b$ ). In agreement with a previous report (21), we also observed the presence of the C3d fragment of C3 localized in the area of the basal membrane in a linear pattern (not shown). Identical distribution of fluorescence was visualized when a monoclonal antibody raised against the $\mathrm{C} 4 \mathrm{~d}$ fragment of $\mathrm{C} 4$ was used in one sample (not shown), but no staining was noted with anti-C4 or anti-C4c antibodies.

We next investigated whether $\mathrm{C} 3$ was secreted by keratinocytes. C3 was isolated from keratinocytes culture supernatants by affinity chromatography using immobilized anti-C3 IgG. After SDS-PAGE, this protein was visualized by immunoblot using the same anti-C3c IgG that was used in the immunofluorescent detection of $\mathrm{C} 3$ in skin and cultured keratinocytes. As shown in Fig. 6, this antibody detected $\mathrm{C} 3$ secreted by the keratinocytes which migrated in the same position as $\mathrm{C} 3$ in human serum. Similar experiments using anti-Factor B antibodies in place of anti-C3 failed to detect specific staining (not shown). Immunofluorescent studies showed Factor B in the cytoplasm of keratinocytes throughout the epidermis, sparing the basal layer (Fig. $7 a$ ). It was also seen in cells in culture (Fig. 7 b). Experiments using corresponding isotypes of nonimmune mouse IgG were negative except for very faint background

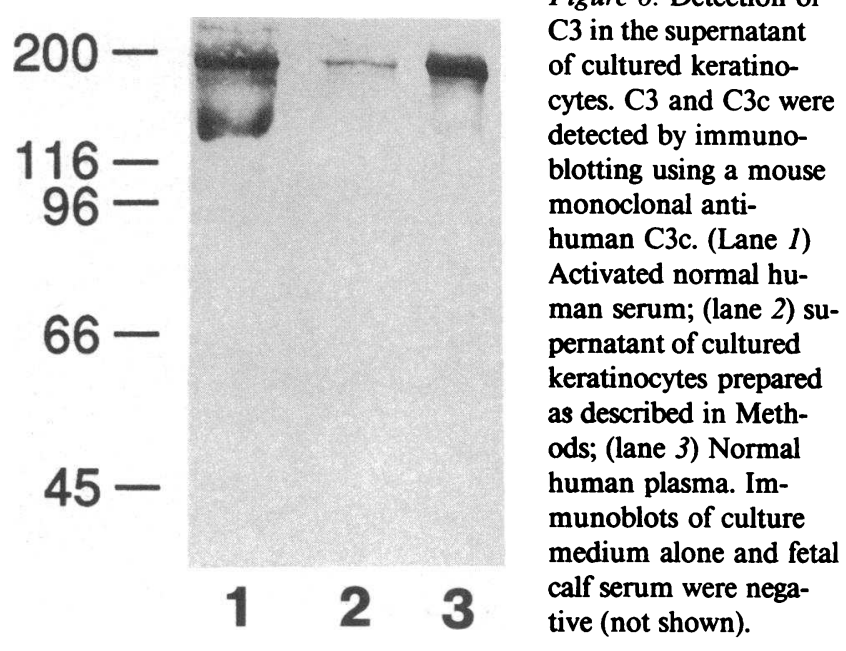

staining of the horny layer (not shown). Direct immunofluorescence of the skin using monoclonal anti-C5, Factor I and Factor $\mathrm{H}$, failed to yield any positive staining (not shown).

\section{Discussion}

Complement proteins have been reported in epithelia and epithelial cell lines (11). Although a number of pathological processes in the skin reveal the presence of complement proteins in the epidermis, little attention has been given to the presence of these proteins in normal epidermis. In part, this may be due to the negative results obtained by routine immunofluorescence analysis of normal skin, leading to the assumption that these proteins are not normally produced by keratinocytes. Therefore, we initiated studies to analyze the presence in the skin of the major complement protein, $\mathrm{C} 3$, and its receptors. Table I summarizes the results of our studies showing that components of the alternative (Factor B and C3) but not the classical (C4) pathways of complement are present in the epidermis. Keratinocytes are capable of synthesizing Factor B and C3. It is likely that in the presence of activators such as microorganisms or immune complexes these components may be cleaved to their enzymatic forms.

The identification of $\mathrm{C} 3$ solely by reaction with this monoclonal antibody was not considered conclusive evidence since others using the same reagent observed a positive reaction not only in the skin of normal individuals, but also in the skin of a patient with a genetic deficiency of $\mathrm{C} 3$ (K. Yancey, personal communication). The latter finding need not be contradictory, because monocytes of $\mathrm{C} 3$ deficient individuals were shown to synthesize $C 3$ in vitro (22). The possibility that our demonstration of $\mathrm{C} 3$ in keratinocytes resulted from cross-reaction of the monoclonal antibody with keratinocytic structures unrelated to $\mathrm{C} 3$ was considered. Western blot analysis of medium of cultured keratinocytes revealed the presence of a single band which migrated at the same position as $\mathrm{C} 3$ in plasma. This result confirms a recent report by Basset-Séguin et al. (23) showing the production of $\mathrm{C} 3$ by metabolically labeled human KC.

The receptor for the $\mathrm{C} 3 \mathrm{~b} / \mathrm{C} 4 \mathrm{~b}$ fragments of complement, CR1, is present on a variety of blood and tissue cells $(24,25)$. It participates in the phagocytic process, and in the clearance of 

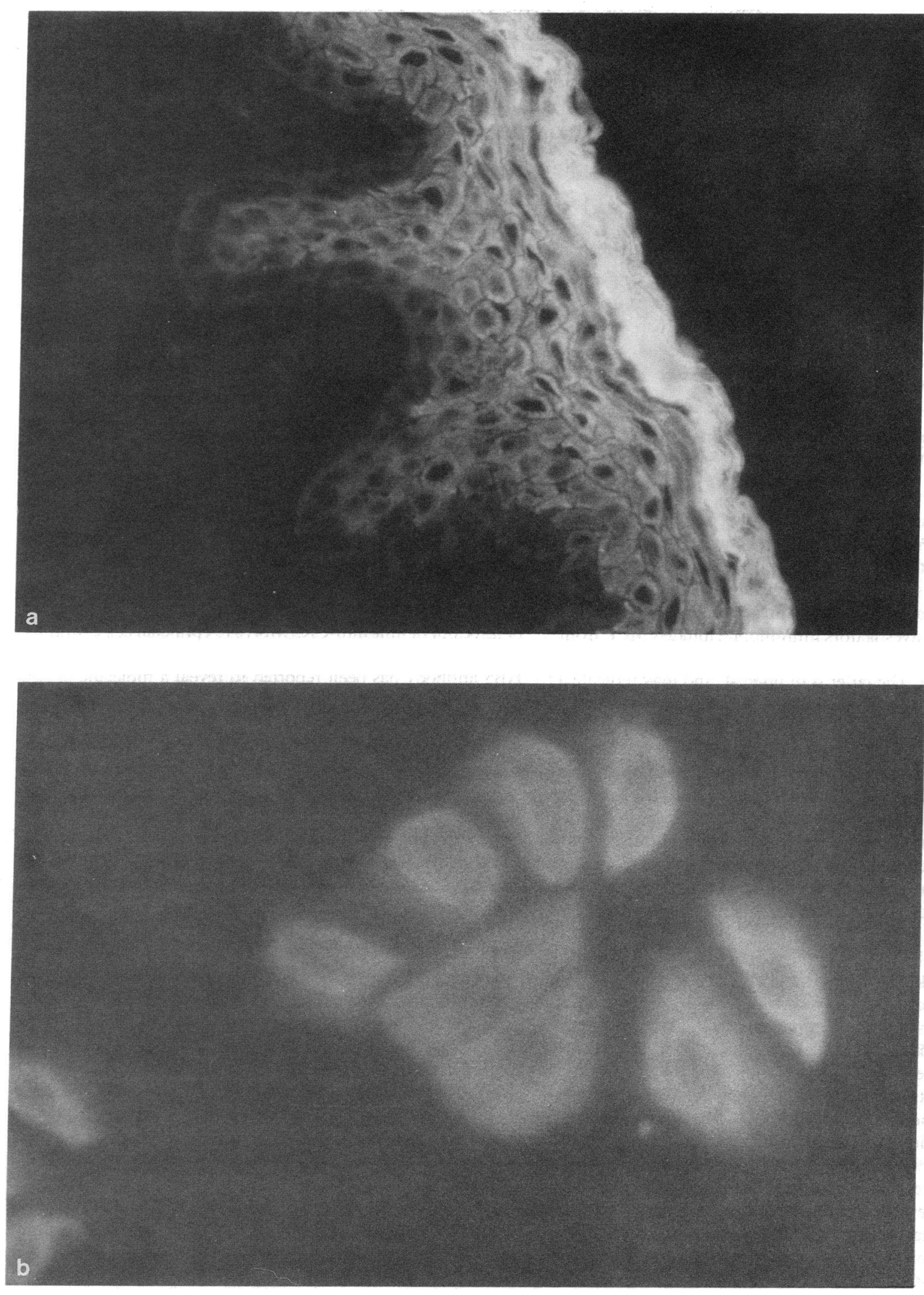

Figure 7. Expression of Factor B in human epidermis. Immunofluorescence of human skin showing Factor B throughout the epidermis sparing the basal cell layer $(a)$. Factor B was also detected in cultured keratinocytes $(b)$. 


\begin{tabular}{|c|c|c|c|c|}
\hline & \multicolumn{2}{|c|}{ Human skin } & \multirow{2}{*}{$\frac{\mathrm{KC}}{\mathrm{IF}}$} & \multirow{2}{*}{$\begin{array}{c}\text { SKC } \\
\text { Western blot }\end{array}$} \\
\hline & $\mathbf{I F}^{\mathbf{s}}$ & $\begin{array}{c}\text { In situ } \\
\text { hybridization }\end{array}$ & & \\
\hline \multicolumn{5}{|l|}{ Component } \\
\hline $\mathrm{C} 3$ & $+(\mathrm{K})^{\| \prime}$ & $n d^{\prime}$ & + & $+(180-k d$ protein $)$ \\
\hline FB & $+(\mathrm{K})$ & nd & + & - \\
\hline $\mathrm{C} 4$ & - & nd & - & nd \\
\hline C3d & $+(\mathrm{DEJ})^{* *}$ & nd & - & nd \\
\hline CR1 & $+($ Basal K) & + & + & nd \\
\hline $\mathrm{CR} 2$ & $+($ Spinous K) & + & - & nd \\
\hline DAF & $+($ Dermis, DEJ, K) & nd & + & nd \\
\hline \multicolumn{5}{|l|}{ Controls } \\
\hline Isotypic IgG & - & & - & \\
\hline Labeled plasmid & & - & & \\
\hline
\end{tabular}

* KC, Cultured keratinocytes. ${ }^{\ddagger}$ SKC, Supernatants of cultured keratinocytes. ${ }^{8}$ IF, Immunofluorescence. " K, Tissue keratinocytes. ' nd, Not done. ** DEJ, Dermoepidermal junction.

immune complexes as well as regulating complement activation $(6,26,27)$. We detected CR 1 on keratinocytes located in the basal layer of the epidermis. Previous studies have reported that another cell surface complement regulatory protein with Factor I cofactor activity, MCP, is present on human epithelial cells (28). These investigators immunoprecipitated MCP from noncutaneous epithelial cell lines, but were unable to detect CR1 or CR2 (28). The latter is of interest, and may indicate a distinct regulatory process for CR1 and CR2 expression in tissues. CR1 has been reported to be absent in the epidermis (29, 30) using $\mathrm{C} 3 \mathrm{~b}$ as the ligand. This difference may be explained by the use of monoclonal antibodies in our experiments which provide higher sensitivity. The demonstration of CR1 mRNA in epidermal keratinocytes by in situ hybridization, further supports the presence of CR1. The expression of this receptor would enable these cells to bind $\mathrm{C} 3 \mathrm{~b}$ molecules which, in conjunction with Factor I, will cleave C3b to C3bi (31). C3bi will remain bound to $C R 1$ and undergo further degradation to C3dg and $\mathrm{C} 3 \mathrm{c}$, or will bind to cells bearing C3bi receptors (CR3) (32). Furthermore, because CR1 functions by accelerating the natural decay of the $\mathrm{C} 3$ and $\mathrm{C} 5$ convertases of both the classical and alternative pathway $(6,33)$, the further generation of activated complement components in the skin will be restricted. CR1, and in particular, its soluble form, has recently been shown to be a very potent inhibitor of complement activation (34), thus its presence on keratinocytes may provide protection from random deposition of $\mathrm{C} 3 \mathrm{~b}$ in a milieu where complement activation is proceeding. Whether $\mathrm{CR} 1$, as it has been shown with other cell types (35), endows keratinocytes with the capability of internalizing particles bearing C3b is not known. Although further research is required to confirm this notion, keratinocytes have been shown to phagocytize erythrocytes under special conditions (36).

The receptor for the C3d fragment of C3 (CR2) has been shown to be the Epstein-Barr virus receptor $(16,37)$. A number of reports have provided evidence that EBV can infect the skin; this virus has been detected in keratinocytes of the skin (38) and mucous membranes of immunosuppressed patients (39). Its receptors (CR2/EBVR) are present, on B lymphocytes, on the surface of cultured cervical epithelial cells, squamous carcinoma cell lines, nasopharyngeal (40), and oral mucosal epithelium (41). In this study, we revealed by immunofluorescence the binding of anti-CR2 MoAb HB5, to the membrane of keratinocytes. Young et al. (40) have recently reported the binding of three out of nine anti-CR2 MoAb to epithelial cells. Immunoprecipitation of metabolically labeled epithelial cells with HB5 antibody has been reported to reveal a molecule of 200 $\mathrm{kD}$ (40) which differs from the $145-\mathrm{kD}$ CR2 precipitated from $B$ cells (42). It was concluded that this size difference may represent posttranslational modifications of the protein, or alternatively, that both are the product of two distinct but related genes. The hybridization of CR2 cDNA to keratinocytes suggests the presence of CR2 mRNA; however, sequencing of the putative epithelial $\mathrm{CR} 2$ will be required to confirm the nature of this molecule and definitely rule out cross-hybridization to a related gene. The presence of CR2 on keratinocytes could provide a port of entry to EBV infection, manifesting itself in disorders of the skin and mucous membranes as reported earlier $(38,39)$. Whether EBV plays a role in other dermatologic diseases remains to be studied. Additionally, CR2 functions as the receptor for the C3d fragment of C3 (7). As such, on B cells, this receptor regulates $B$ cell responses, particularly to $T$ cell products. Differentiation and proliferation of $B$ cells have been reported using cross-linked C3d or anti-CR2 antibodies (43-48). These studies suggest that cross-linking CR2 on cell surfaces is involved in regulating $B$ cell activation. Therefore, it may be speculated that it could have regulatory effects in epidermal cell proliferation through its interaction with its ligand, C3d.

DAF is a glycoprotein present on the surface of neutrophils, monocytes, lymphocytes, platelets $(49,50)$ and a variety of human epithelial cells as well as in a soluble form in body fluids (51). The only known function of DAF consists in accelerating the decay of the classical and alternative pathway C3 and C5 convertases $(9,52)$. This is believed to control the functional presence and deleterious effects of these enzyme complexes on the surface of autologous cells during complement activation, where $\mathrm{C} 3 \mathrm{~b}$ may be randomly deposited on their membranes. DAF has been reported to be present on the periphery of elastic 
fibers in the skin (20), as well as on the surface of keratinocytes (53). In our study, a similar distribution of DAF was observed, but we were also able to identify it along the basal membrane of the epidermis. A possible function for DAF at this location could consist in preventing the deposition of the products of complement activation in this location. Whether DAF at that site is the result of local production or entrapment of the circulating soluble form of this glycoprotein is not known. Overall, these studies indicate that since the epidermis is continuously exposed to foreign antigens, the local synthesis of complement proteins may contribute to the effective processing of these antigens. In the presence of activators of complement, locally produced $\mathrm{C} 3$ and epidermal proteases may generate $\mathrm{C} 3 \mathrm{~b}$ and contribute to the formation of the initial $\mathrm{C} 3$ convertase of the alternative pathway. Deposited C3b may be further cleaved generating fragments that may interact with complement receptors on keratinocytes and immunocompetent cells. It is postulated that stimulation of complement receptors on keratinocytes may exert similar differentiation effects as seen on B cells.

\section{Acknowledgments}

The authors wish to thank Susan Krayzel and Teresa Torbett for their secretarial support. The authors also wish to thank Ms. Angie Grimes from Clonetics Co., San Diego, CA, for providing isolated bovine pituitary extract present in $\mathrm{KGM}^{\mathrm{TM}}$.

This research was supported by grants AI20067 and AI20476 from the National Institutes of Health. Dr. Dovezenski is a recipient of a grant from the Scientific Foundation of the Republic of Serbia, Yugoslavia.

\section{References}

1. Gigli, I., and F. A. Tausk. 1987. Human complement system. In Dermatology in General Medicine. T. B. Fitzpatrick, A. Z. Eisen, K. Wolff, I. M. Freedberg, and K. F. Austen, editors. McGraw-Hill Inc., New York. 442-456.

2. Müller-Eberhard, H. J. 1984. The membrane attack complex. Springer Semin. Immunopathol. 7:93-141.

3. Nilsson, U. R., and H. J. Müller-Eberhard. 1965. Isolation of beta IF-globulin from human serum and its characterization as the fifth component of complement. J. Exp. Med. 122:277-298.

4. Nelson, R. A., J. Jensen, I. Gigli, and N. Tamura. 1966. Methods for the separation, purification and measurement of nine components of hemolytic complement in guinea pig serum. Immunochemistry. 3:111-135.

5. Ferreira, A., M. Takahashi, and V. Nussenzweig. 1977. Purification and characterization of mouse serum protein with specific binding affinity for C4 (SS protein). J. Exp. Med. 146:1001-1018.

6. Fearon, D. B. 1979. Regulation of the amplification C3 convertase of human complement by an inhibitory protein isolated from human erythrocyte membrane. Proc. Natl. Acad. Sci. USA. 76:5867-5871.

7. Ross, G. D., M. J. Polley, E. M. Rabellino, and R. M. Grey. 1973. Two different complement receptors on human lymphocytes, one specific for $\mathrm{C} 3 \mathrm{~d}$ and one specific for C3b inactivator-cleaved C3b. J. Exp. Med. 138:798-811.

8. Seya, T., J. Turner, and J. P. Atkinson. 1986. Purification and characterization of a membrane protein (gp 45-70) that is a cofactor for cleavage of C3b and C4b. J. Exp. Med. 163:837-855.

9. Nicholson-Weller, A., J. Burge, D. T. Fearon, P. F. Weller, and K. F. Austen. 1982. Isolation of a human erythrocyte membrane glycoprotein with decay-accelerating activity for $\mathrm{C} 3$ convertases of the complement system. J. Immunol. 129:184-189.

10. Zalman, L. S., L. M. Wood, and H. J. Müller-Eberhard. 1986. Isolation of a human erythrocyte membrane protein capable of inhibiting expression of homologous complement transmembrane channel. Proc. Natl. Acad. Sci. USA. 83:6975-6979.

11. Cole, F. S., and H. R. Colten. 1988. In The Complement System. K. Rother and G. O. Till, editors. Springer-Verlag, Heidelberg.

12. Tausk, F. A., J. A. McCutchan, P. Spechko, R. D. Schreiber, and I. Gigli.
1986. Altered erythrocyte C3b receptor expression, immune complexes, and complement activation in homosexual men in varying risk groups for acquired immune deficiency syndrome. J. Clin. Invest. 78:977-982.

13. Boyce, S. T., and R. B. Ham. 1983. Calcium-regulated differentiation of normal human epidermal keratinocytes in chemically defined clonal culture and serum-free social culture. J. Invest. Dermatol. 81:35s-40s.

14. Laemmli, U. K. 1970. Cleavage of structural proteins during the assembly of the head of bacteriophage T4. Nature (Lond.). 227:680-685.

15. Klickstein, L. B., T. J. Bartow, V. Miletic, L. D. Rabson, J. A. Smith, and D. T. Fearon. 1988. Identification of distinct $\mathrm{C} 3 \mathrm{~b}$ and $\mathrm{C} 4 \mathrm{~b}$ recognition sites in the human $\mathrm{C} 3 \mathrm{~b} / \mathrm{C} 4 \mathrm{~b}$ receptor $(\mathrm{CR} 1, \mathrm{CD} 35)$ by deletion mutagenesis. J. Exp. Med. 168:1699-1717.

16. Moore, M. D., N. R. Cooper, B. F. Tack, and G. R. Nemerow. 1987. Molecular cloning of the cDNA encoding the Epstein-Barr virus/C3d receptor (complement receptor type 2) of human B lymphocytes. Proc. Natl. Acad. Sci. USA. 84:9194-9198.

17. Maniatis, T., E. F. Fritsch, and J. Sambrook. 1989. Molecular Cloning: A Laboratory Manual. Cold Spring Harbor Laboratory, Cold Spring Harbor, NY.

18. Stürzl, M., and W. K. Roth. 1990. "Run-off" synthesis and application of defined single-stranded DNA hybridization probes. Anal. Biochem. 185:164169.

19. Lanzillo, J. J. 1990. Preparation of digoxigenin-labeled probes by the polymerase chain reaction. Biotechniques. 8:620-622.

20. Werth, V. P., I. E. Ivanov, and V. Nussenzweig. 1988. Decay-accelerating factor in human skin is associated with elastic fibers. J. Invest. Dermatol. 91:511516.

21. Basset-Séguin, N., M. Dersookian, K. Cehrs, and K. Yancey. 1988. C3d,g is present in normal human epidermal basement membrane. J. Immunol. 141:1273-1280.

22. Einstein, L. P., P. J. Hansen, M. Ballow, A. E. Davis, J. S. Davis, C. A. Alper, F. S. Rosen, and H. R. Colten. 1977. Biosynthesis of the third component of complement (C3) in vitro by monocytes from both normal and homozygous C3 deficient humans. J. Clin. Invest. 60:963-969.

23. Basset-Séguin, N., S. W. Caughman, and K. B. Yancey. 1990. A-431 cells and human keratinocytes synthesize and secrete the third component of complement. J. Invest. Dermatol. 95:621-625.

24. Berman, B., and I. Gigli. 1980. Complement receptors on guinea pig epidermal Langerhans cells. J. Immunol. 124:685-690.

25. Fearon, D. T. 1980. Identification of the membrane glycoprotein that is the C3b receptor of the human erythrocyte, polymorphonuclear leukocyte, B lymphocyte and monocyte. J. Exp. Med. 152:20-30.

26. Cornacoff, J. D., L. A. Herbert, W. L. Smead, M. E. van Aman, D. J. Birmingham, and F. J. Waxman. 1983. Primate erythrocyte immune complex clearing mechanism. J. Exp. Med. 71:236-247.

27. Medof, E., and V. Nussenzweig. 1984. Control of the function of substrate-bound C4b-C3b by the complement receptor CR1. J. Exp. Med. 159:16691685.

28. NcNearney, T., L. Ballard, T. Seya, and J. P. Atkinson. 1989. Membrane cofactor protein of complement is present on human fibroblast, epithelial, and endothelial cells. J. Clin. Invest. 84:538-545.

29. Schreiber, L., and R. Penny. 1979. Tissue C3b receptors. Clin. Exp. Immunol. 38:316-322.

30. Thyresson, H. N. M., F. C. McDuffie, and A. L. Schroeter. 1981. C3b receptor in normal human skin. J. Invest. Dermatol. 77:353-357.

31. Medof, M. E., K. Iida, C. Mold, and V. Nussenzweig. 1982. Unique role of the complement receptor $\mathrm{CR} 1$ in the degradation of $\mathrm{C} 3 \mathrm{~b}$ associated with immune complexes. J. Exp. Med. 156:1739-1754.

32. Ross, G. D., J. D. Lambris, J. A. Cain, and S. L. Newman. 1982. Generation of three different fragments of bound $\mathrm{C} 3$ with purified factor I or serum. I. Requirements for factor H vs. CR1 cofactor activity. J. Immunol. 129:20512060.

33. Wilson, J. G., W. W. Wong, P. H. Schur, and D. T. Fearon. Mode of inheritance of decreased $\mathrm{C} 3 \mathrm{~b}$ receptors on erythrocytes of patients with systemic lupus erythematosus. N. Engl. J. Med. 307:981-986.

34. Weisman, H. F., T. Bartow, M. K. Leppo, H. C. Marsh, Jr., G. R. Carson, M. F. Concino, M. P. Boyle, K. H. Roux, M. L. Weisfeldt, and D. T. Fearon. 1990. Soluble human complement receptor type 1: in vivo inhibitor of complement suppressing post-ischemic myocardial inflammation and necrosis. Science (Wash. DC). 249:146-151.

35. Gigli, I., and R. A. Nelson. 1968. Complement dependent immune phagocytosis. I. Requirements for C1, C4, C2, C3. Exp. Cell Res. 51:45-67.

36. Schenk, P. 1986. Erythrophagocytosis in Kaposi's sarcoma in acquired immune deficiency syndrome. ORL (Oto-Rhino-Laryngol.) (Israel). 48:167-173.

37. Fingeroth, J. D., J. J. Weis, T. F. Tedder, J. L. Strominger, P. A. Biro, and D. T. Fearon. 1984. Epstein-Barr virus receptor of human B lymphocytes is the C3d receptor C2. Proc. Natl. Acad. Sci. USA. 81:4510-4514.

38. Fermand, J.-P., J. Gozlan, A. Bendelac, M.-C. Delauche-Cavallier, J.-C. 
Brouet, and F. Morinet. 1990. Detection of Epstein-Barr virus in epidermal skin lesions of an immunocompromised patient. Ann. Intern. Med. 112:511-515.

39. Greenspan, J. S., D. Greenspan, and E. T. Lennette. 1985. Replication of Epstein-Barr virus within the epithelial cells of oral "hairy" leukoplakia, an AIDS associated lesion. N. Engl. J. Med. 313:1564-1571.

40. Young, L. S., C. W. Dawson, K. W. Brown, and A. B. Rickinson. 1989. Identification of a human epithelial cell surface protein sharing an epitope with the C3d/Epstein-Barr virus receptor molecule of B lymphocytes. Int. J. Cancer. 43:786-794.

41. Corso, B., L. F. Eversole, and L. Hutt-Fletcher. 1989. Hairy leukoplakia: Epstein-Barr virus receptors on oral keratinocyte plasma membranes. Oral Surg. Oral Med. Pathol. 67:416-421.

42. Deleted in proof

43. Tedder, T. F., J. J. Weis, L. T. Clement, D. T. Fearon, and M. D. Cooper. 1986. The role of receptors to complement in induction of polyclonal B-cell proliferation and differentiation. J. Clin. Immunol. 6:65-73.

44. Perri, R. T., B. S. Wilson, and N. E. Kay. 1986. Inhibition of B cell growth factor (BCGF) by monoclonal antibodies directed against the $\mathrm{C} 3 \mathrm{~d}$ receptor (CR2). Eur. J. Immunol. 16:350-355.

45. Carter, R. H., M. O. Spycher, Y. C. Ng, R. Hoffman, and D. T. Fearon 1988. Synergistic interaction between complement receptor type 2 and membrane IgM and B lymphocytes. J. Immunol. 141:457-463.

46. Wilson, B. S., J. L. Platt, and N. E. Kay. 1985. Monoclonal antibodies to the 140,000 molecular weight glycoprotein of B lymphocyte membranes (CR2 receptor) initiates proliferation of B cells in vitro. Blood. 66:824-829.

47. Frade, R. 1986. Structure and functions of gp 140, the C3d/EBV receptor (CR2) of human B lymphocytes. Mol. Immunol. 23:1249-1253.

48. Melchers, F., A. Erdei, T. Schult, and M. P. Dierich. 1985. Growth control of activated synchronized murine $B$ cells by the $\mathrm{C} 3$ fragment of human complement. Nature (Lond.). 317:264-267.

49. Nicholson-Weller, A., J. P. March, C. E. Rosen, D. B. Spicer, and K. F. Austen. 1985. Surface membrane expression by human blood leukocytes and platelets of decay-accelerating factor, a regulatory protein of the complement system. Blood. 65:1237-1244

50. Kinoshita, T., M. E. Medof, R. Silber, and V. Nussenzweig. 1985. Distribution of decay-accelerating factor in the peripheral blood of normal individuals and patients with paroxysmal nocturnal hemogobinuria. J. Exp. Med. 162:7592.

51. Medof, M. E., E. I. Walter, J. L. Rutgers, D. M. Knowles, and V. Nussenzweig. 1987. Identification of the complement decay-accelerating factor (DAF) on epithelium and glandular cells and in body fluids. J. Exp. Med. 165:848-864.

52. Fujita, T., T. Inoue, K. Ogawa, K. Iida, and N. Tamura. 1987. The mechanism of action of decay-accelerating factor (DAF). DAF inhibits the assembly of C3 convertases by dissociating $\mathrm{C} 2 \mathrm{a}$ and Bb. J. Exp. Med. 166:1221-1228.

53. Sayama, K., S. Shiraishi, Y. Shyirakata, Y. Kobayashi, and Y. Miki. 1991. Characterization of decay-accelerating factor (DAF) in human skin. J. Invest. Dermatol. 96:61-64. 